\title{
Taxes, Financial Markets and the Great Moderation
}

\author{
Orhan Erem Ateşağaoğlu* \\ Istanbul Bilgi University
}

\begin{abstract}
Recent studies have shown that there was a noticeable decline in the US corporate sector business cycle volatility from roughly the mid-1980s until the start of the recent financial crisis in 2007. This fact came to be known as the Great Moderation. During the same period, tax rates on US corporate distributions fell roughly from $43 \%$ to $17 \%$ as a result of the changes in the US income tax system that took place in the early $1980 \mathrm{~s}$. Motivated by these, we investigate the effects of dividend tax cuts on macroeconomic volatility. We develop a model in which firms finance investment through external equity and internal funds, and face costs of reducing labor input. Dividend taxes reduce the amount of external equity that new firms raise, so they start small and grow over time by using internal funds to a greater extent. Such financially constrained firms respond more to the business cycle shocks since they are less affected by labor reduction costs because of their growing labor demand on their life cycle. Contrarily, old and large firms respond less to business cycle shocks since they have completed their growth process, and are therefore more affected by labor reduction costs. Lower dividend taxes induce firms to issue more external equity and become financially unconstrained in a shorter amount of time, so there are fewer small, volatile firms, and therefore lower volatility in macroeconomic indicators.
\end{abstract}

Keywords: business cycles, dividend taxes.

JEL Classifications: E10, E32, E62.

\section{Vergiler, Finansal Piyasalar ve Büyük Moderasyon}

\section{Özet}

Son yıllardaki araştırmalar, ABD kurumsal sektör volatilitesinde 1980'lerin ortalarından son mali krizin başlamasına kadar belirgin bir düşüş olduğunu gösterdi. Literatürde bu dönem "Büyük Moderasyon" olarak bilinmektedir. Aynı dönemde, ABD kurumsal temettü vergi oranları 1980’lerin başında gerçekleşen vergi sistemindeki değişiklikler nedeniyle yaklaşık \%43'ten \%17'ye düştü. Bu makalede, temettü vergilerinin makroekonomik oynaklık üzerindeki etkilerini araştırıyoruz. Bu bağlamda, firmaların dış

* Orhan Erem Ateşağaoğlu is an Assistant Professor in the Department of Management at Istanbul Bilgi University, Santral Istanbul, Kazim Karabekir Cad. No: 2/13, Eyup, Istanbul, Turkey. E-mail: erem.atesagaoglu@bilgi.edu.tr. 
sermaye ve dahili fonlar yoluyla yatırım finanse ettikleri ve işten çıkartma maliyetleriyle karşı karşıya kaldıkları bir model geliştirdik. Temettü vergileri dış finansman maliyetini arttırdığ 1 için, yeni firmalar küçük ölçekli başlayarak daha çok dahili fonları kullanarak zamanla büyümeye başlarlar. Dış finansman maliyeti yüksek olan bu tür firmalar büyüme evresinde oldukları için makroekonomik şoklar karşısında işci cıkartma maliyetlerinden daha az etkilenmektedirler ve bu nedenle daha fazla tepki vermektedirler. Buna karşın, eski ve büyük firmalar büyüme sürecini tamamladıkları için makro şoklar karşısında işci çıkartma maliyetlerinden daha fazla etkilenmektedirler ve bu nedenle daha az tepki vermektedirler. Bu bağlamda, düşük temettü vergileri, yeni ve küçük firmaları daha fazla dış finansman kullanarak kısa bir sürede büyüme evresini tamamlamaya yönlendirir ve, sonuç olarak, ekonomide daha az sayıda küçük şirketin ve daha fazla büyük şirketin yer almasını sağlayarak makro volatilitenin düşmesini sağlamaktadır.

Anahtar kelimeler: iş döngüleri, kar payı vergileri.

JEL Siniflandirmast: E10, E32, E62.

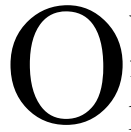

ver the past century, macroeconomic variables have experienced significant fluctuations over the growth trend. Economist called these asymmetric and persistent deviations as Business Cycles and a significant body of explanations has been proposed to explain the certain properties of these movements. The main influence on that literature, Kydland-Presott (1982), showed that the business cycle volatility was roughly constant in US, and by taking a supply side view, they showed that the productivity shocks could account for most of the post-WWII period.

Recent studies have shown that there was a noticeable decline in the US corporate sector business cycle volatility from roughly the mid-1980s until the start of the recent financial crisis in 2007. This historical fact came to be known as the Great Moderation and has been documented by many, including Clark (2009), Den Haan and Sterk (2011), Philippon (2016), among others. Now it is a certain fact that, starting from the first quarter of 1984, all macroeconomic variables, including Total Factor Productivity (TFP) display a lower volatility, until the start of the "Great Recession" in 2007 (Figure 1, Table 1). ${ }^{[1]}$ Especially the two recessions experienced in early 1990 s and 2001 were milder with respect to earlier historical ones. The timing of this fact can be seen more clearly in Figure 1, which plots the cyclical component of corporate GDP. ${ }^{[2]}$ A similar pattern is also observed for all real macroeconomic variables including investment, consumption, employment and TFP (Table 1). Finally, Figure 2, which plots the five year moving average of corporate sector output growth volatility, shows more clearly

\footnotetext{
[1] While it seems that the Great Moderation period lasted till 2007, we end up our macro data analysis in 2004 (see Figure 1, Table 1). The reason for that is related to the causality that is proposed in this paper and will be clarified below. Nonetheless, this omission is not crucial for the data analysis and the quantitative results that we provide.

[2] The cyclical component of corporate GDP is obtained by using a Band-Pass filter that preserves cycles from 1.5 to 8 years. Alternative filters obtain very similar results.
} 
the timing of the beginning: starting from 1984, a Great Moderation observed in the volatility of macroeconomic indicators until the start of the Great Recession. ${ }^{[3]}$

Figure 1

\section{Corporate GDP (Deviations from Trend)}

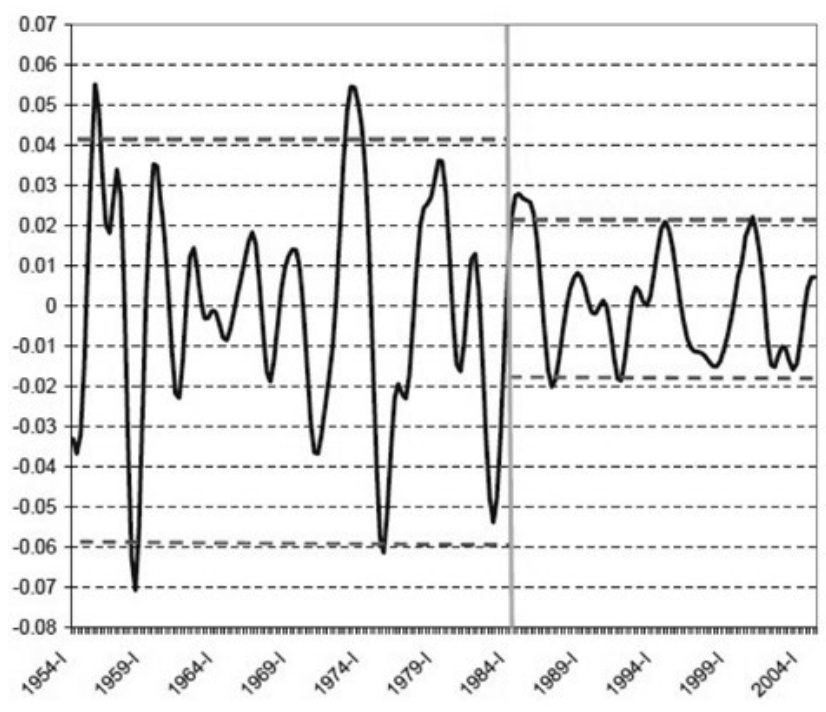

Table 1

Real and Financial Market Statistics

\begin{tabular}{cccc}
\hline \hline & $1954-1984$ & $1984-2004$ & LATE / EARLY \\
\hline REAL DEVIATIONS & & & \\
Output & 2.24 & 1.23 & 0.55 \\
Investment & 5.98 & 4.15 & 0.69 \\
Consumption & 1.22 & 0.53 & 0.43 \\
Labor & 2.21 & 1.10 & 0.50 \\
TFP & 0.74 & 0.42 & 0.57 \\
\hline FINANCLAL VARIABLES & & & \\
$\quad$ Tobin's q & 0.76 & 1.14 & 1.49 \\
\hline \hline
\end{tabular}

Notes: All standart deviations are Band-Pass filtered that preserves cycles that has length between 1.5 to 8 years.

[3] While the literature has a consensus that the Great Moderation started in mid-1980s, the recent financial crisis in 2007 started a big debate about if the Great Moderation came to end. The general consensus in the literature is that the Great Recession of 2007 put an end to the Great Moderation period (The literature review section provides a discussion on this point). 
Figure 2

\section{GDP Volatility (Moving Average)}

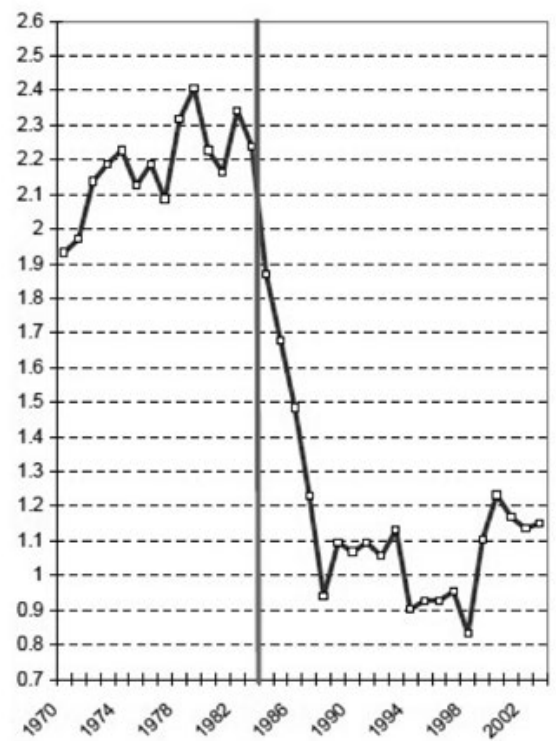

On the other hand, during the post-1984 period, some other important changes took place in the U.S. corporate sector which increased the flexibility of firms in external equity markets, especially for small and young firms.

Equity financing increased its importance during the Great Moderation period. NASDAQ, which has been a source of financing for small and young firms, started to increase its importance in the1980s. Especially, the increase in the number of new IPOs and the increasing share of NASDAQ's market capitalization and trading volume facilitated the access of small and young firms to equity markets. Secondly, the number of publicly traded firms increased and the average IPO age decreased in the1980s and 1990s. ${ }^{[4]}$ Thirdly, but more importantly, while the new and young firms experienced substantial growth and rise in their stock market capitalization, incumbent old firms experienced a stagnation in their stock market capitalization during the Great Moderation. More in details, the value of U.S. corporate sector begin to rise starting mid-1980s; while the value over replacement cost for U.S. corporate sector was around 0.76 between 19541984, it increased to a level of 1.14 and stayed at that level on average Table 1, Figure 5). ${ }^{[5]}$ But most of the post-1984 rise was because of increase in market capitalization of new and young firms. ${ }^{[6]}$ Finally, the venture capital funds, which are important financing sources especially for starting and expanding companies, experienced a boom in the last two decades, starting in the earl-1980s. In summary, the evidences listed lead

\footnotetext{
[4] For documentation of these two facts, see Jovanovic-Rousseau (2001) and Comin-Philippon (2005).

[5] McGrattan-Prescott(2005), Hall(2001) and Laitner-Stolyarov(2003) documented the dynamics of U.S. Corporate Sector Tobin's q.

[6] This point is discussed more in details by Hobjin-Jovanovic(2001) and Jovanovic-Rousseau(2002).
} 
us to a conclusion that, young, small and risky business experienced a financing boom during the Great Moderation period.

The claim proposed in our paper is that the elimination of the distortions created by the old U.S. Income Tax Act generated the changes in financial markets listed above, which contributed the observed decline in macroeconomic volatility. There had been radical changes in the Income Tax Act beginning in the early 1980s that decreased the income tax rates and narrowed the progressive tax brackets. Since the dividend payout of corporations are considered as a part of regular household income, they are affected by the changes of the Act. After the changes in the tax system, the effective marginal dividend tax rate fell roughly from $43 \%$ in 1981 to $16.8 \%$ in 1988 and this directly affected the equity financing decision of corporations. Our argument is that, the observed decline in dividend taxes acted as one of the contributing factors to the Great Moderation.

As it can be seen in Figure 3 and Figure 4, the timing of the decrease in marginal dividend tax rates and macroeconomic volatility coincides in the mid-80s. In addition to that, as Figure 5 shows, the timing of the decrease in dividend tax rates and increase in value of corporations coincides, where McGrattan and Prescott (2005) argue that the observed increase in Tobin's q from the mid-1980s to 2000s was a result of the increase in corporate valuations due to reduction in dividend taxes in the early-1980s. ${ }^{[7]}$ These two facts are interpreted as important evidences for our proposed hypothesis.

Figure 3

\section{GDP Volatility and Dividend Tax}

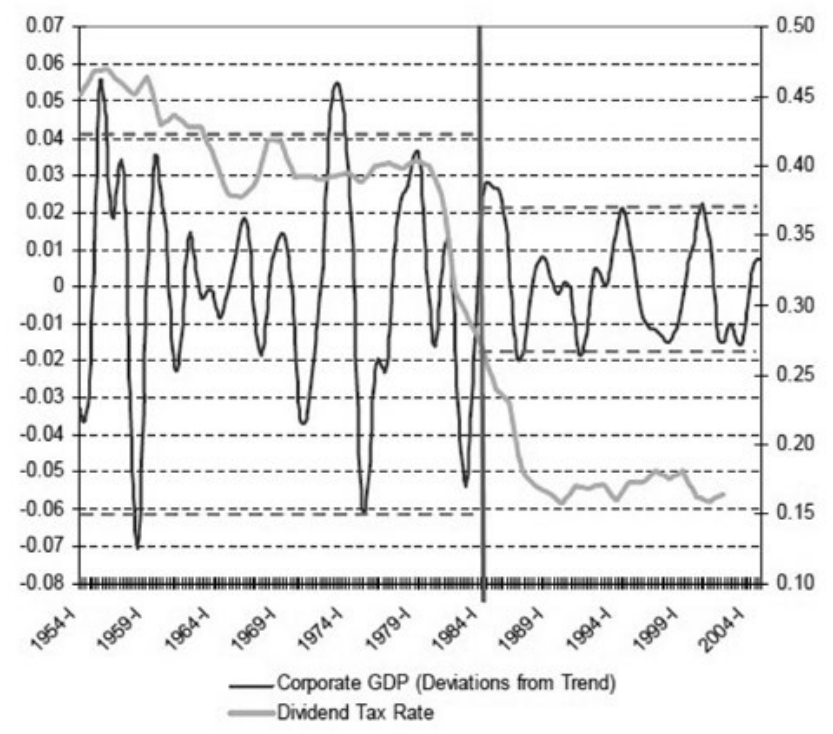

[7] The literature has a couple of alternative explanation for the oberved increase in Tobin's q since the mid-1980s. Greenwood and Jovanovic (1999) argues that the ICT revolution was the cause of the increase in stock prices over the period of interest. McGrattan and Prescott (2005) argues that the reduction in dividend taxes in the early-1980s led to the observed rise in Tobin's q. Hall (2001) attributes the rise in the market value of equity to higher intangible investment during the 1990's. 
Figure 4

Taxes and Macroeconomic Volatility

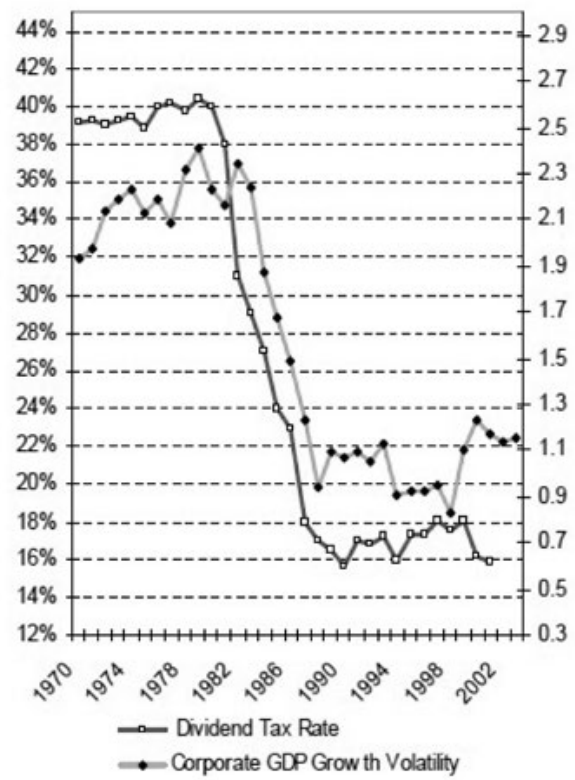

Figure 5

Taxes and Tobin's $q$

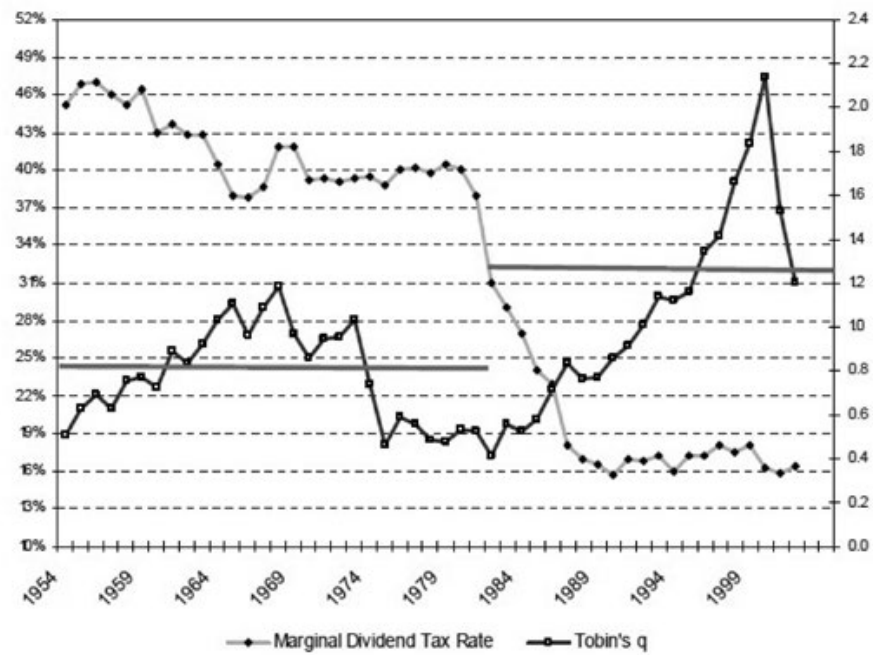


In this paper, we propose an explanation within a general equilibrium model with heterogeneous firms, where dividend taxes affect the investment decision, and therefore a particular period of the life cycle of corporations. In each period, two kinds of firms exist endogenously in the model economy: financially constrained small and young firms, and financially unconstrained old and large firms. All firms finance their investment with internal funds and external equity, and face the cost of reducing their labor inputs. With higher dividend taxes, young and small firms choose to raise less external equity in the beginning of their life-cycle. Such firms start small and grow over time slowly by using internal funds to a greater extent. These financially constrained firms experience a longer growth period since the internal funds generated are bounded by the operational capacity which limits their investment. Therefore, the financial constraints endogenously exist in the economy because of the distortions created by the tax system.

On the other hand, such financially constrained and growing firms respond more to the business cycle shocks since they are affected less by the labor reduction costs. Because of their growing labor demand on their life cycle, such firms respond to business cycle shocks easily by changing the level of increase in their labor input, which is not affected by labor reduction costs. Contrarily, the old and large firms that have completed their growth process respond less to the business cycle shocks since they are affected more by the labor reduction costs. For such firms, employing more workers in booms can be costly during downturns because of the accrual of labor reduction costs.

The business cycle volatility of the macroeconomic indicators are affected by the share of each type of firm in the model economy. The more financially constraint firms exist, the more volatile is the economy. With lower dividend taxes, young and small firms choose to raise more external equity and become financially unconstrained in a shorter amount of time. As a result, the number and output share of financially constrained and growing firms decreases, which causes lower volatility in macroeconomic indicators. ${ }^{[8]}$

Therefore, the decline in dividend taxes is proposed as one of the contributing factors to the decline in macroeconomic volatility starting in early 1984: The Great Moderation.

According to my knowledge, this work will be the first to study the structural effects of the tax system on business cycle fluctuations. The model is used to investigate the extent to which the observed changes can be accounted for qualitatively and quantitatively, by the changes in U.S. income tax act and regulatory system.

The paper is organized as follows: Section 2 discusses the literature, section 3 summarizes the changes in the U.S. income tax act and regulatory system, section 4 builds the main model and characterizes the general equilibrium environment, section 5 shows the effect of dividend taxes on investment and financing decisions of the firms, section 6 calibrates the model and reports the qualitative and quantitative results and Section 7 concludes.

[8] Gertler-Gilchrist (1994) documents the differential response of small and large firms in US manufacturing sector during business cycle contractions. This fact is discussed more in details in section 6 . 


\section{Related Literature}

The literature that focused on the documentation of the decline in U.S. macro volatility that started in the mid-1980s is quite extensive. McConnell and Perez-Quiros (2000) were among the first to document and discuss the reasons of that trend. Clarida, Gali \& Gertler (2000) argue that the change in monetary policy rule during the VolckerGreenspan period has affected the response of the economy to business cycle shocks. Kahn, McConnell \& Perez-Quiroz (2002) argue that improvements in the inventory management systems developed during the last two decades has contributed to the reduction in macroeconomic volatility. Blanchard-Simon (2001) argue that in addition to the changes in both inventory management techniques and monetary policy, reduction in the government spending volatility is an important factor. Contrarily, the findings of Leduc \& Sill (2006) shows that the changes in monetary policy are not a factor that significantly affected the observed trend in macroeconomic volatility. Ahmet et al. (2002), Arias et al. (2007) and Gordon (2005) claim that good luck during the post-1984 period is the only cause of lower macroeconomic volatility. An important contribution comes from Gali and Gambetti (2009), showing that the Great Moderation can be largely explained by a sharp fall in the contribution of nontechnology shocks, and, by contrast, the contribution of technology shocks to output volatility appears to have remained largely stable. Accordingly, models investigating the underlying causes of the Great Moderation need to focus on reasons other than possible changes in the volatility of TFP shocks.

A second branch of work focuses on the effect of changes in financial markets on the Great Moderation. Campbell-Hercowitz (2005) argues that the financial reforms that took place in the early 1980s have changed the propagation mechanism by relaxing the collateral constraints on household borrowing. Dynan et al. (2006) argue that Regulation Q (partially phased out between 1981 and 1986) as a contributing factor to the Great Moderation On the firm side, Jermann-Quadrini (2006) proposed that, the financial innovations in corporate debt and equity markets are the main reasons for the decrease in macroeconomic volatility. Their proposed explanation is based on the increased financial flexibility that makes equity-debt swap easier, which decreases propagation effect of borrowing constraints on output. There had been various innovations in credit markets during the 1980s, such as junk bonds and asset-backed securities, which has also been quoted as a major contributing factors to the Great Moderation. Bulow et al. (1990) argue that the development of junk bonds (high-yield debt) was a response to the U.S. tax system of the time. In particular, Shoven and Waldfogel (1990) argue that the Economic Recovery Tax Act of 1981 increased the incentives for debt financing which, in turn, led to the development of the junk bond market. Thus, in this view, the causality between the incentives for debt financing and credit market innovations runs from the former to the latter. ${ }^{[9]}$

[9] In our setup, if we define debt constraints and define them as being constrained by a collateral value that depend on the market value of capital $V(k)$, the decline in dividend taxes will lead to an increase in the market value of capital stock and, therefore, an increse in the level of debt. In this setup, firms will be unconstrained in a shorter period of time, 
Finally, another branch of work focuses on the effect of changes in microeconomic volatility at the firm level. Philippon (2003) claims that, starting early 1980s there was an increase in microeconomic volatility, and builds a model in which the increase in competition can explain the decrease in macroeconomic volatility and higher microeconomic volatility. Contrarily, Campbell-Fisher (2004) builds a model with labor adjustment costs at the firm level and argues that the decrease in microeconomic volatility is the main cause of lower macroeconomic volatility. ${ }^{[10]}$

As can be seen from the list of papers cited above, the literature that focused on the underlying causes of Great Moderation slowed down after the Great Recession in 2007, due to the fact that macro volatilities went back to their pre-1984 levels over the period of 2007-2009. Clark (2009) shows that the Great Moderation statistics ended with the start of the financial recession in 2007. Den Haan and Sterk(2011) argues that the financial innovations that were initiated in the early 1980s were not the cause of the Great Moderation, but they led to a financial recession in 2007 which put and end to the Great Moderation period. Ball (2010) argues that the Great Moderation ended with the recession if 2007, and an important work for future work is the performance of monetary prolicy regimes in this new high volatility world. Taylor (2013) and Philippon (2016) had similar arguments, stating that the Great Recession marked the end of the Great Moderation period.

This paper complements these studies by focusing on the role played by the fiscal policy and links the financial markets explanation to the changes in the income tax act. In addition, since the tax rates are taken from the data, the model allow us to make progress on the quantitative analysis of the Great Moderation.

\section{Major Changes in U.S. Tax and Regulatory System}

Two major changes were observed in the early 1980s and both caused a significant reduction in the effective marginal dividend tax rate on corporate distributions.

The first one was the key policy change that took place at the time of Ronald Wilson Reagan, the 40th president of the United States. As a part of Reagan's supply-side economics policy, generally referenced as Reaganomics, the new Income Tax Act decreased the tax rates and narrowed the progressive tax brackets in the early 1980s. The Economic Recovery Tax Act (1981), which reduced the highest tax rate from 70\% to $50 \%$, was the largest tax cut in American history. Following that, Tax Reform Act of 1986 (TRA-1986) reduced the highest income tax rate from $50 \%$ to $28 \%$. These rate reductions implied a drop in marginal rates paid on dividends, since dividends are taxed as ordinary income.

which will enhance the effects of the decline in dividend taxes on decline in macro volatility, which will enhance our conjecture.

${ }^{[10]}$ There is a debate about the changes at micro volatility in the literature. While Philippon (2003) and Comin-Philippon (2005) argue that micro volatility increased, they use a data set that covers only publicly traded firms. However, the work of Davis et al. (2006) which uses LBD database that covers all private sector firms in US, shows that the microeconomic volatility declined more than $\% 40$ since 1982 . They claim that the rise in microeconomic volatility among publicly traded firms is accounted by the higher volatility of more recently listed entrants. 
The second change that affected the marginal dividend tax rate was a change at regulations governing pension funds and retirement accounts, which do not pay tax on distributions. ERISA (Employment Retirement Income Security Act), enacted in 1974, sets minimum standards for pension plans in private industry. It was enacted to protect interstate commerce and the interests of participants in employee benefit plans and their beneficiaries, by requiring the disclosure and reporting to participants and beneficiaries of financial and other information with respect thereto, by establishing standards of conduct, responsibility, and obligation for fiduciaries of employee benefit plans, and by providing for appropriate remedies, sanctions, and ready access to the Federal courts. The new uniform fiduciary standards were revised and improved in 1979 by the U.S. Depart-ment of Labor (Section404(a)(1) of Rules and Regulations for Fiduciary Responsibility). Before ERISA, most of the pension funds were composed of debt assets since a decrease at the corporate value could bring the risk of fiduciaries being sued. Therefore, the equity holdings of pension funds increased significantly after the legal changes. ${ }^{[11]}$ After these changes, with the help of the new tax act, pension fund and retirement account equity holdings increased significantly. The percentage of corporate equity held by all non-taxed accounts increased from $4 \%$ in 1960 s to $51 \%$ in 2000 s.

As a consequence of these two major reforms, changes in income tax act and regulations caused a significant decline in effective marginal tax rates on corporate distributions, which decreased roughly from $43 \%$ to $16.8 \%$ from 1981 to $1988 .{ }^{[12]}$

\section{Model}

First, we describe the environment in which an individual firm operates. After characterizing the firm's problem, we describe the remaining parts of the model and define the general equilibrium. Thereafter, we look at the effect of dividend taxes on the behavior of a single firm.

The time is discrete, denoted by $t=1,2,3, \ldots$ and the horizon is infinite. There are three types of agent in our economy: households, firms and the government. Firms are the production resources in the economy and they are owned by the households. The government sets the tax rates on dividends and distributes the tax revenues to the households as a lump sum transfer.

\section{Firms}

At each point in time, there is a continuum of firms that have access to the production technology:

$$
y=F(k, l ; z)
$$

where $\mathrm{k}$ is the input of capital, 1 is the input of labor and $\mathrm{z}$ is the aggregate level of productivity. We assume that $\mathrm{F}$ is strictly increasing and continuously differentiable in

\footnotetext{
${ }^{[11]}$ Source: Prescott-McGrattan (2005).

${ }^{[12]}$ Source: Prescott-McGrattan (2005).
} 
$\mathrm{k}$ and $\mathrm{l}$. In addition, $\mathrm{F}$ satisfies the standard Inada conditions and is strictly concave in $\mathrm{k}$ and $\mathrm{l}$, which implies $\mathrm{F}$ is a decreasing returns to scale production function. The assumption of decreasing returns to scale implies that the firms generate positive profit and their market value is above the replacement cost of capital input.

We assume that the firms are subject to a quadratic cost of reducing labor input:

$$
\varphi\left(l_{t-1}, l_{t}\right)=\left\{\begin{array}{cc}
\kappa\left(\frac{l_{t-1}-l_{t}}{l_{t-1}}\right)^{2} l_{t-1} & \text { if } l_{t}<l_{t-1} \\
0 & \text { otherwise }
\end{array}\right\}
$$

where $l_{t}$ and $l_{t-1}$ denote labor input in time-t and time t-1 respectively. The function $\phi($.$) captures different aspects of cost of reducing labor inputs such$ as: firing costs, cost of managerial time in reallocating tasks from destroyed job spots to other positions, organizational and human capital loss generated by the jobs destructed etc. ${ }^{[13]}$

We assume that firms raise funds with external equity and retained earnings to finance investment. ${ }^{[14]}$ At each point in time, firms are characterized by the amount of capital they own, $k$, and the previous period labor input, $l_{-1}$. The cum-dividend value $V\left(k, l_{-1} ; s\right)$ will thus depend on the state of the firm, $k$ and $l_{-1}$. The equity value also depends on the aggregate state of the economy, $s$, which will be made precise below.

For notational convenience, we define the vector $a=\left(k, l_{-1}\right)$ as the individual state of the firms. In addition, current capital and previous period labor input are defined on $A=A_{k} x A_{l} \subseteq R_{+} x R_{+}$, which implies $a \in A$. Since the only source of heterogeneity among firms is the differences in firm level capital and previous period labor input, the model yields a Borel measure $\mu: B(A) \rightarrow[0,1]$ that represents the cross sectional distribution of firms over $A$. In equilibrium, the distribution $\mu($.$) also represents the portfolio shares$ of corporations for the households.

The shocks in our economy are introduced as wage shocks $w$, and this is the sole source of aggregate uncertainty in our model ${ }^{[15]}$ For convenience, we assume that the

${ }^{[13]}$ Hopenhayn-Rogerson(1993) discusses the taxes on job destruction and focuses on the welfare and employment consequences of firing costs. Gonzales-Johri(2002) focuses on the affect of loss of firm specific organizational capital associated with labor adjustment on aggregate employment. Campbell-Fisher $(2000,2004)$ discusses the cost of managerial time interpretation in more in details. Finally, the convexity assumption of the labor reduction cost is consistent within the literature and discussion of it is beyond the scope of this paper.

${ }^{[14]}$ In this version of the model, we do not have debt financing. There are two reasons for that exclusion. If we add debt financing to the current version of the model with no restrictions, all firms will reach to their optimal level of capital stock in just one period, by borrowing/lending the right amount of debt. Accordingly, in a sensitivity analysis, we incorporated debt into our model with borrowing constraint, where borrowing/lending in period-t $\left(b_{t+1}\right)$ is constrained by the next period capital stock $\left(k_{t+1}\right)$ multiplied by a collateral constant $(\kappa)$. The simulations showed that the quantitative effects of incorporating debt financing into our model is quite small. Accordingly, we find that the Modigliani-Miller Theorem almost holds -- the user cost of equity is more or less equal to the cost of debt financing imposed by the debt ceiling. Based on these results, we decided to exclude the debt financing from our model since (i) first, results are not affected significantly, and (ii) there are several other ways of incorporating debt into such models (default models, exogenous debt costs, etc.) and it would be more convenient to abstain from such discussions.

${ }^{[15]}$ The structure and interpretation of these kinds of shocks will be discussed in the next section. 
shocks are common across firms and follow a markov chain, $\left\{w_{-1}, \ldots, w_{J}\right\}$, where ${ }^{[16]}$

$$
P\left(w^{\prime}=w_{j} / w=w_{i}\right)=\pi_{i j} \quad \text { and } \quad \sum_{j=1}^{J} \pi_{i j} \quad \text { for all } i=1, \ldots, J
$$

The aggregate states of the economy is then given by the wage rate $w$, and the beginning of period distribution of firms $\mu .{ }^{[17]}$ The set of aggregate state variables is denoted by $s=(w, \mu)$ and the cross sectional distribution of firms evolves over time according to a mapping, $\Gamma$, which varies with aggregate state of the economy, $\mu^{\prime}=\Gamma(w, \mu)$. The firms and the households need the law of motion $\Gamma(s)$ to solve their optimization problems. This function is taken as given by the agents and will be described in detail below.

The households purchase a diversified portfolio of firm shares. In addition, we assume that $q\left(w_{j}, \mu^{\prime} ; w, \mu\right)$ is the relevant stochastic discount factor applied by firms to their next period ex-pected discounted cum-dividend value if current period wage shock is $\mathrm{w}$ and next period wage shock is $w_{j}$. Simply, $q\left(s^{\prime} ; s\right)$ denotes the price of an Arrow security that will deliver one unit of consumption good next period if $w=w j$. In equilibrium, these state-contingent prices are equal to the pricing kernels implied by the household's utility maximization problem.

In each period, firms faces a probability $\varphi$ of becoming unproductive. Such firms exit before any production and investment decision take place. They are replaced with new entrants that start the period with zero capital and no labor input history, such that the mass of firms operating is constant over time. Therefore, $\varphi$ is the relevant entry and exit rates in our economy. The capital of firms that exit becomes unproductive and loses its market and replacement cost value. This last assumption is consistent with the empirical evidence documenting the low resale price of used capital for existing firms.

A surviving firm makes investment $i$ to change the capital stock, after the aggregate uncertainty $s$ observed. The firm level capital stock depreciates at the rate $\delta \in(0,1)$ and changes according to the following standard law of motion:

$$
k^{\prime}=(1-\delta) k+i
$$

Conditional on survival, the firm chooses the input of labor $l$, dividend payout $d$ , new issued equity $e$ and investment $i$. The optimization problem of firms, taking the evolution of the distribution of firms $\mu^{\prime}=\Gamma(w, \mu)$ as given, can be written as:

$$
\begin{aligned}
V\left(k, l_{-1} ; w, \mu\right)=\max \left\{\left(1-\tau_{d}\right) d-e+(1-\phi) \sum_{j=1}^{J} \pi_{i j} q\left(w_{j}, \mu^{\prime} ; w, \mu\right) V\left(k^{\prime}, l ; w_{j}, \mu^{\prime}\right)\right\} \\
\text { s.t. } \quad \begin{aligned}
d & =F(k, l ; z)-i-w l-\varphi\left(l, l_{-1}\right)+e \\
k^{\prime} & =(1-\delta) k+i \\
d & \geq 0 \\
e & \geq 0
\end{aligned}
\end{aligned}
$$

\footnotetext{
${ }^{[16]}$ Throughout the paper, primes indicate one-period-ahead values.

${ }^{[17]}$ Throughout the paper, we drop the index for current wage shock and represent $w_{i}$ as $w$.
} 
where, $\tau_{d}$ is the tax rate on dividends. If the firm issue new shares and use outside equity, $e>0$. The equation (6) describes the flow of funds for the firm and inequality (8) denotes the non-negativity condition on dividend payments. By condition (9), we assume that share repurchases are not allowed in our economy. In the United States, share repurchases were allowed but not preferred as a distribution method by the corporations until the 2000s. The main reason at the back of that was, SEC and IRS rules treated share repurchases as dividends, and therefore there was no tax advantage prior to 1982 . On the other hand, SEC adoption of the safe harbor rule (Rule 10b-18) in 1982 allowed corporations to buy back shares and avoid the ordinary income taxes. But with the 1981 and 1986 tax acts, the difference in tax rate on capital gains and dividends disappeared, and therefore so did the incentives for the share repurchases. As a consequence, share repurchases had not been considered as the primary method for corporate payouts until the 2000s. For simplicity, we follow most of the papers in the literature and impose a condition (9) to capture the observed trend. ${ }^{[18]}$

The state-contingent discount factors used by the firms depend on the aggregate state of the economy. Therefore, firms and households need to keep the track of evolution of firm size distribution. Given the computational difficulties of dynamic stochastic heterogeneous agent models, firm size distribution is approximated with some of its moments following the methodology introduced by Krusell-Smith (1998). From now on, throughout the paper, $\Gamma(s)$ denotes the law of motion of moments that represents the true firm size distribution.

\section{Households}

There is a unit mass of households with the momentary utility represented by the financial form:

$$
U(c)
$$

where $c$ denote households consumption. We assume that labor supply of households is perfectly elastic and independent of the intertemporal consumption-saving choice. First of all, this particular form of preferences is selected for computational considerations. Similar ways of modeling the household preferences is actually common in heterogeneous agents stochastic general equilibrium models, which simplifies the computational complexities significantly. ${ }^{[19]}$ Secondly, rather than being a drawback, this implication of the preferences has the advantage of emphasizing the alternative propagation mechanism generated by the dividend taxes studied. ${ }^{[20]}$

Households owns a diversified portfolio of shares, and therefore, they only face the aggregate risk. ${ }^{[21]}$ In each period, the stockholders receive dividend receipts that are

\footnotetext{
${ }^{[18]}$ Poterba-Summers(1983), Auerbach(2002) and Dietz(2003) use the same type of constraint on share repurchases.

${ }^{[19]}$ See Krusell-Smith (1997-1998) and Castaneda, Dias-Gimenez and Rios-Rull(1997) for similar examples.

${ }^{[20]}$ The functional form assumed to represent the preferences is discussed more in details in the next section. The version of the model with preferences displaying imperfect elasticity of labor is an ongoing research.

${ }^{[21]}$ Since, in equilibrium, households hold the same portfolio of shares of existing firms, we ignore the transactions of trading in shares.
} 
taxed as ordinary income. This fact is modeled as a single tax rate and will be taken from the data as the marginal dividend tax rate on US corporate distributions. The relevant budget constraint is:

$$
c+\phi e^{n}=w l^{s}+(1-\phi) \int\left[\left(1-\tau_{d}\right) d(a ; s)-e^{s}(a)\right] \theta(d A)+T
$$

where $w$ is the current wage rate (shock), $e^{n}$ is equity investment in new firms, $e^{s}(a)$ is new equity investment in existing firms, $d(a ; s)$ is the dividend payout policy of each type of firm which is taken as given by the households, $\theta($.$) is the distribution of portfolio$ shares and $T$ is the transfers to households from the government. The labor supply of the household, $l^{s}$, is determined by the aggregate labor demand of the firms because of our assumption of perfectly elastic labor supply.

The households choose consumption $c$, equity investment in new firms $e^{n}$, and equity investment in existing firms $e^{s}(a)$. The recursive maximization problem of the household, taking the law of motion of distribution of firms $\mu^{\prime}=\Gamma(w, \mu)$ as given, can be written as:

$$
\begin{aligned}
W(\theta ; w, \mu) & =\max \left\{U(c)+\beta \sum_{j=1}^{J} \pi_{i j} W\left(\theta^{\prime} ; w_{j}, \mu^{\prime}\right)\right\} \\
\text { subject to } c+\phi e^{n} & =w l^{s}+(1-\phi) \int\left[\left(1-\tau_{d}\right) d(a ; s)-e^{s}(a)\right] \theta(d A)+T \\
\theta^{\prime} & =\psi\left(\theta, s, e^{n}\right)
\end{aligned}
$$

where the function $\psi($.$) defines the evolution of portfolio of shares. This function$ depends on the current portfolio share of the firms $\theta$, set of aggregate states $s$, and the level of equity issued by new firms $e^{n}$. $^{[2]}$ The first order conditions of household problem imply:

(i) stochastic discount factor pricing kernel:

$$
q\left(s^{\prime} ; s\right)=\frac{\beta U_{c}\left(s^{\prime}\right)}{U_{c}(s)}
$$

\section{Government}

The government sets the level of taxes, collects the tax revenues and rebates to the households in a lump sum manner. We abstract from the distortions generated from the financing of government spending by tax revenues. The government budget constraint takes the form of:

$$
T(s)=(1-\phi) \int \tau_{d} d(a ; s) \mu(d A)
$$

\footnotetext{
${ }^{[22]}$ The function $\psi$ is defined since the trading in shares is ignored in our model. The evolution of portfolio shares $\psi$ is equal to the law of motion of firm size distribution $\Gamma$. The definition of separate functions is just to avoid confusion between the concepts of an endogenous decision function and exogenous law of motion function.
} 


\section{Business Cycle Shocks and the Steady State Analysis}

The economic uncertainty in our economy is modeled as wage shocks that affect the labor demand of the firms directly. ${ }^{[23]}$ The wage shocks follow a two-state markov process and take values, wl and wh, where wl corresponds to a good shock since lower wages will increase the labor input demand of firms. The shocks evolve according to symmetric transition matrix:

$$
\left(\begin{array}{cc}
\pi & 1-\pi \\
1-\pi & \pi
\end{array}\right)
$$

where $\pi$ also represents the persistence of the shocks.

The extension of the model to imperfectly elastic labor is still an ongoing research. On the other hand, for a complete analysis of the affects of income tax act reform on US economy, we should focus on the effect of lower dividend taxes on macroeconomic variables in terms of level changes, the comparison of steady states. How the competitive markets for both capital and hours worked were affected by the reforms is an important factor that should be considered. Contrarily, the functional form for preferences that is used in the business cycle analysis is not consistent with the standard Kaldor's stylized balanced growth path facts. To solve that problem, we assume that the households have utility from leisure and labor supply is not perfectly elastic in the long run. Therefore, preferences in our steady state analysis takes the functional form of: ${ }^{[24]}$

$$
U\left(c, 1-l^{s}\right)
$$

which implies a general equilibrium market clearing wage. In conclusion, our assumptions about the preferences imply perfectly elastic labor supply in the short run (unemployment) and imperfect elasticity of labor supply in the long run (hours). ${ }^{[25]}$

\section{Definition: Recursive Equilibrium}

A recursive competitive equilibrium consists of:

(a) Households decision rules $c(s), e^{n}(s), e^{s}\left(k, l_{-1} ; s\right)$ and value functon $W(\mu ; s)$;

(b) Firms decision rules $d\left(k, l_{-1} ; s\right), e\left(k, l_{-1} ; s\right), l\left(k, l_{-1} ; s\right), i\left(k, l_{-1} ; s\right)$ and the value function associated with the firms problem $V\left(k, l_{-1} ; s\right)$;

(c) Law of motion $\Gamma(s)$ for distribution of firms $\mu$;

Such that:

(i) Optimality (HH): The decision rules $c(s), e^{n}(s)$ and $e^{s}\left(k, l_{-1} ; s\right)$ solves household problem and $W(\mu ; s)$ is the associated value function;

(ii) Optimality (Firms): The decision rules $d\left(k, l_{-1} ; s\right), e\left(k, l_{-1} ; s\right)$,

\footnotetext{
${ }^{[23]}$ See Campbell $(2001,2004)$ for the interpretation of wage shocks as a source of job creation and destruction.

${ }^{[24]}$ The recursive general equilibrium is defined for the preferences used in our business cycle analysis. The definition of steady state equilibrium follows a similar logic.

${ }^{[25]}$ As an example, our preference assumption can be represented by a variation of Greenwood-Hercowitz-Huffman preferences with different long run and short run labor supply elasticities.
} 
$l\left(k, l_{-1} ; s\right), \quad i\left(k, l_{-1} ; s\right)$ solves the firms optimization problem and $V\left(k, l_{-1} ; s\right)$ is the associated value function;

(iii) Discount factors are competitive and capital markets clear,

(iv) The government budget constraint is satisfied.

(v) The law of motion of distribution of firms is consistent with the individual decision rules.

The computation of state-contingent discount factors is a difficult task in the current formulation of firm's problem. It is easier to compute equilibrium by reformulating the firm's problem by using the equilibrium implications of household utility maximization. It will then be possible to define simpler functional forms that give the endogenous prices as a function of aggregate state. For that, let $w(s)$ denote the price that plants use to value the current production, where

$$
\varpi(s)=u_{c}(s)
$$

The discount factor pricing kernel from household maximization problem implies that

$$
q\left(s^{\prime} ; s\right)=\beta \frac{\varpi\left(s^{\prime}\right)}{\varpi(s)}
$$

After reformulating the firm's equity value in terms of utility of the households, firm's optimization problem can be written as:

$$
\begin{aligned}
v\left(k, l_{-1} ; w, \mu\right) & =\max \left\{\varpi(s)\left[\left(1-\tau_{d}\right) d-e\right]+(1-\phi) \beta \sum_{j=1}^{J} \pi_{i j} v\left(k^{\prime}, l ; w_{j}, \mu^{\prime}\right)\right\} \\
\text { s.t. } \quad d & =F(k, l ; z)-i-w l-\varphi\left(l, l_{-1}\right)+e \\
k^{\prime} & =(1-\delta) k+i \\
d & \geq 0 \\
e & \geq 0
\end{aligned}
$$

The first order conditions with respect to capital, $k$, labor, $l$, dividend payout, $d$, and new equity investment, $e$, are:

$$
\begin{aligned}
(1-\phi) \beta\left(\sum_{j=1}^{J} \pi_{i j} \xi\left(k^{\prime}, l ; s^{\prime}\right)\left[F_{k}\left(k^{\prime}, l^{\prime} ; z\right)+(1-\delta)\right]\right) & =\xi\left(k, l_{-1} ; s\right) \\
(1-\phi) \beta\left(\sum_{j=1}^{J} \pi_{i j} \xi\left(k^{\prime}, l ; s^{\prime}\right) \varphi_{l}\left(l^{\prime}, l\right)\right) & =\xi\left(k, l_{-1} ; s\right)\left(F_{l}\left(k^{\prime}, l^{\prime} ; z\right)-w+\varphi_{l}\left(l, l_{-1}\right)\right) \\
\varpi(s)\left(1-\tau_{d}\right)+\lambda_{d}\left(k, l_{-1} ; s\right)-\xi\left(k, l_{-1} ; s\right) & =0 \\
-\varpi(s)+\lambda_{e}\left(k, l_{-1} ; s\right)+\xi\left(k, l_{-1} ; s\right) & =0
\end{aligned}
$$

where $\xi, \lambda_{d}$ and $\lambda_{e}$ are the Lagrange multipliers respectively for flow of funds equation (6), non-negativity condition on dividends (8) and no share buyback condition (9).

The reformulation of firms' problem implies that the firms need to know price $w$ to solve their problem. Contrary to state-contingent discount rates, $w$ depends only on the current state of the economy. We assume that the function $\Omega(s)$ gives the endogenous price $w$ as a function of current aggregate states, $s$. As a consequence, given the firms 
know the law of motion $\Gamma(s)$ and the pricing function $\Omega(s)$, the problem of firms is well defined.

\section{The User Cost Effect of Dividend Taxes}

To understand the user cost of dividend taxes and its effect on the life cycle of firms, the problem of new firms and mature firms are analyzed separately in the deterministic version of the model. First, we focus on the effect of dividend taxes on investment decision. Secondly, we analyze how the financing policy of firms is affected by distortions created by the tax system.

\section{The Poblem of New Firms}

The new firms will start their life cycle with no capital and no previous employment history. There will be no production and the firms will not distribute any dividends to finance their initial level of capital. The problem of a new firms is:

$$
V(0,0)=\max _{e}\left\{-e+\frac{(1-\phi)}{(1+r)} V(e, 0)\right\}
$$

The equity raised by the new firms in their first period is equal to the next period capital input. The firms will determine their investment level to equate the marginal cost of one unit of external equity raised to its marginal benefit:

$$
\begin{aligned}
\text { MarginalCost : } V_{k}(k, 0) & =\frac{1+r}{1-\phi} \\
\text { Marginal Benefit : } V_{k}(k, 0) & =\left(1-\tau_{d}\right)\left[F_{k}(k, l ; z)+(1-\delta)\right]
\end{aligned}
$$

While the marginal cost of external equity (31) is not affected by he dividend taxes, the marginal benefit of investment (32) is affected. With no dividend taxes, the firms raise the required amount of external equity to reach the optimum level of capital. Contrarily, when dividends are taxed, firms issue a lower level of equity and start their life cycle from a lower level of capital. Figure 6 illustrates the optimal investment policy of new firms. 
Figure 6

Investment Policy of New Firms

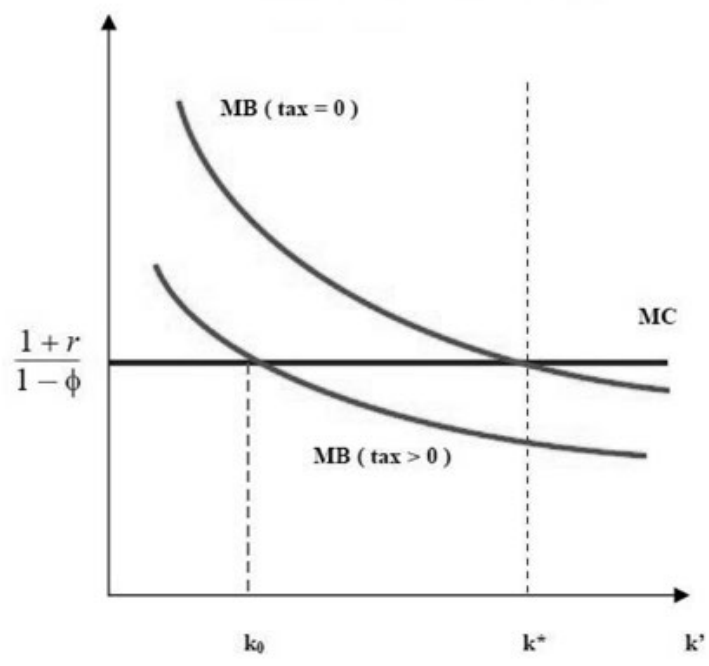

\section{The Problem of Mature Firms}

Firms that reach their optimal level of capital start distributing dividends and use a part of the retained earnings to replace the depreciated level of capital. Since the internal funds that are distributed are taxed, any resources shifted from corporate distributions to investment are tax deductible. The marginal cost of investment for mature firms is equal to $\left(1-\tau_{d}\right)(1+r) /(1-\phi)$ and lower than the marginal cost of external equity, $(1+r) /(1-\phi)$. The first order condition associated with the investment decision of mature firms is:

$$
\frac{(1+r)}{(1-\phi)}=F_{k}(k, l ; z)+(1-\delta)
$$

which implies that the dividend taxes do not distort the investment decision of mature firms. The financing policy of the firms is affected by the dividend taxes. From the first order conditions of the firm's problem, we obtain the following key equation:

$$
\lambda_{d}\left(k, l_{-1}\right)+\lambda_{e}\left(k, l_{-1}\right)=\tau_{d}
$$

If $\tau_{d}=0$, the equation (34) implies that the both lagrange multipliers $\lambda_{d}$ and $\lambda_{e}$ are equal to 0 . The firms are indifferent between any equity-dividend policy as long as the total payout is the same. The Modigliani-Miller theorem holds and the capital structure is irrelevant.

Contrarily, if dividend taxes are positive, $\tau_{d}>0$, the capital structure matters for the investment decision of the firms. It is optimum for the firms not to issue equity and distribute dividends at the same time because of the user cost effect of dividend taxes. Three different financing options take place at different phases of the life cycle of corporations: 
Case I - External Equity Financing ( $\tau_{d}>0$ and $\left.\lambda_{e}=0\right)$ : The complementary slackness conditions imply $\mathrm{d}=0$ and $\mathrm{e} \geq 0$. Firms do not have enough internal funds to finance investment and distribute dividends. Therefore, corporations retain all the earnings and issue external equity to finance investment.

Case II - Internal Funds Financing ( $\tau_{d}>0$ and $\lambda_{e}>0$ ): The complementary slackness conditions imply $\mathrm{d}=0$ and $\mathrm{e}=0$. Firm use all internal funds to finance investment and do not distribute any dividends. On the other hand, corporations do not issue outside equity also since the marginal cost of outside equity is higher than its marginal benefit. Due to share dilution, marginal return to investment does not justify the reduction in corporations' value.

Case III - Dividend Distribution ( $\tau_{d}=0$ and $\lambda_{e}>0$ ): The complementary slackness conditions imply $\mathrm{d} \geq 0$ and $\mathrm{e}=0$. Firm have enough internal funds to finance investment and distribute dividends. Therefore, corporations do not issue outside equity.

New firms are set up using new outside equity. The corporation does not prefer to jump to optimum level of capital directly since the marginal benefit at optimum level of capital is lower than the marginal cost of outside equity. The firms start to grow to a mature state by retaining all funds and not distributing dividends but also not issuing external equity. The firms start distributing dividends when they reach the mature level and no profitable investment opportunities exists (Figure 7).

Figure 7:

\section{Financing Policy}
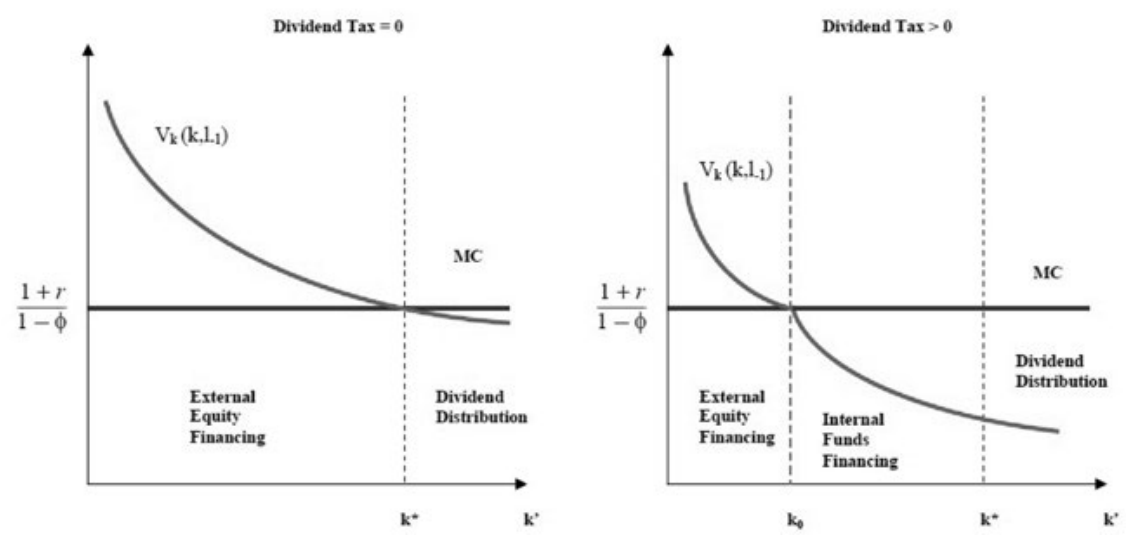

Figure 8 illustrates the evolution of the size of a representative firm on its life cycle for general standard functional forms for production technology and reasonable parameterizations in a partial equilibrium setting. When $\tau_{d}=0$, the corporation directly jumps to the optimum capital level. On the other hand, with positive dividend tax rates, the corporations experience a transition period till they reach the optimum capital level. 
Figure 8

Firm Size Evolution

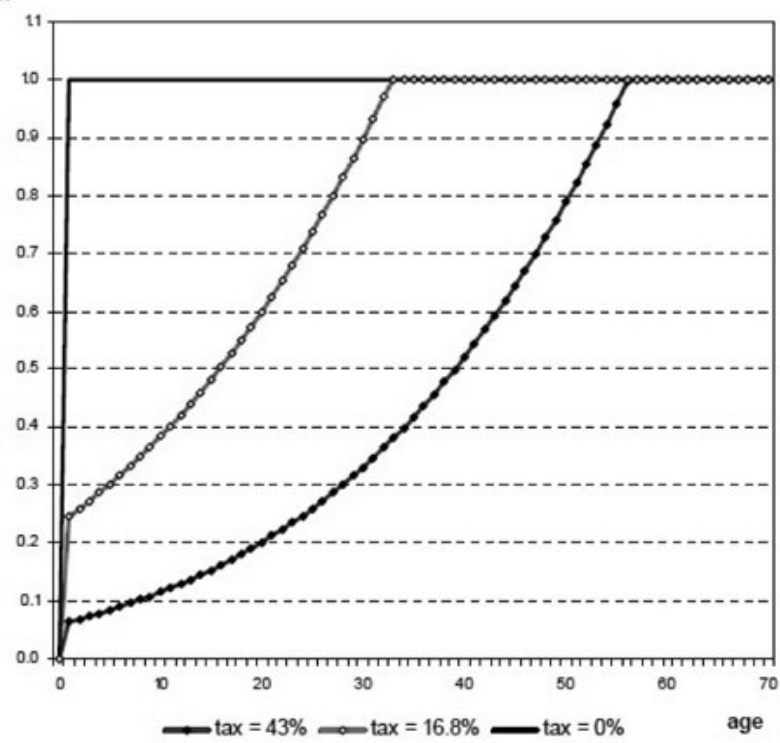

In a deterministic environment, the labor reduction costs are not important since the labor input of firms never decreases over their life cycle. Therefore the user cost of dividends on investment decision is independent of the labor reduction costs. On the other hand, the cost of reducing labor input affects the business cycle dynamics of the firms, which is analyzed in the next section.

\section{Quantitative Results}

The model is calibrated on a quarterly basis. The discount rate is set to $\beta=0.99$ that implies a quarterly net interest rate $r=0.01$ in steady state, which is close to its observed value in the data. The momentary utility function of the household in steady state analysis takes the form $\ln (c)+m \cdot \ln \left(1-l_{t}\right)$. The consumption-leisure tradeoff parameter $\mathrm{m}$ is chosen so that one third of available time is spent working when dividend tax rates are at their pre-reform level. The momentary utility function in business cycle analysis takes the functional form $\ln (c)$.

The exit rate for firms is set to $\phi=0.025$. This number implies an annual exit rate of $10 \%$, which is the approximate annual value for US economy as reported by the $\operatorname{OECD}(2001)$. The production function is specified as $y=z .\left(k^{\alpha} l^{1-\alpha}\right)^{v}$. The returns to scale parameter is set to 0.97 to match the Tobin's q at its pre-reform level and this number is consistent within the corporate finance literature. ${ }^{[26]}$ Based on returns to scale parameter, parameter $\alpha$ is set so that the labor income share of unconstrained firms is

[26] For example, this number is cited as 0.95 in the paper of Gomes (2001) and 0.961 in papers of Gourio and Miao (2010, 2012). 
equal to 0.66 , which is close to the observed labor income share in corporate sector. The depreciation rate for capital is set to $\delta=0.025$ which is consistent with the data analysis of McGrattan-Prescott (2005). The aggregate technology level of the economy, z, is chosen such that the input of capital of mature firm is equal to 1 before the tax reform, which is a simple normalization that does not affect the results.

Following Cooley and Quadrini (2001), the persistence probability of wage shocks is set to 0.95 which implies that the average duration of a cycle is 20 quarters. The standard deviations of wage shocks which is implicitly implied by the wage shocks $w_{l}$ and $w_{h}$, and the labor adjustment cost $\kappa$ are two key parameters in our analysis. These two parameters are picked to match jointly the output volatility before the tax reform and the volatility difference between financially constrained and unconstrained firms. Based upon our knowledge, there are no data resources or data analysis that can be used for the calibration of these parameters. Therefore, we will calibrate our model for reasonable target values for the volatility difference. The full set of parameters are reported in Table 2 .

Table 2

Parameter Values

\begin{tabular}{lcc}
\hline Intertemporal discount rate & $\beta$ & 0.99 \\
Capital share of income & $\alpha$ & 0.32 \\
Span of control & $v$ & 0.97 \\
Depreciation rate & $\delta$ & 0.025 \\
Technology level & $z$ & 0.196 \\
Consumption - leisure share & $m$ & 0.146 \\
Exit rate & $\phi$ & 0.025 \\
Persistence of wage shocks & $\pi$ & 0.95 \\
Standard deviation of shocks & $w_{l}, w_{h}$ & varies \\
Labor reduction cost & $\kappa$ & varies \\
\hline
\end{tabular}

\section{Steady State Comparison}

Before studying the response of the economy to business cycle shocks, we focus on the effect of income tax act reform on levels, the comparison of steady states. Therefore, the competitive markets for both capital and hours worked affected by the reforms is an important factor that should be considered.

Figure 9 illustrates the evolution of the size of a representative firm on its life cycle. When the dividend tax rate is $43 \%$, new firms start with an input of capital equal to $7 \%$ of the capital level of financially unconstrained firms and reach the unconstrained status in approximately 15 years. When dividend tax rates are lowered to $16.8 \%$, the new firms start with a higher capital input since the marginal benefit of external equity finance increases with lower dividend taxes. Firms reach financially unconstrained status at a shorter time, approximately 8 years. ${ }^{[27]}$

\footnotetext{
${ }^{[27]}$ The firm size distribution is an important aspect. Even though there is detailed data for the US economy on firm size
} 
Figure 9

\section{Firm Size Evolution}

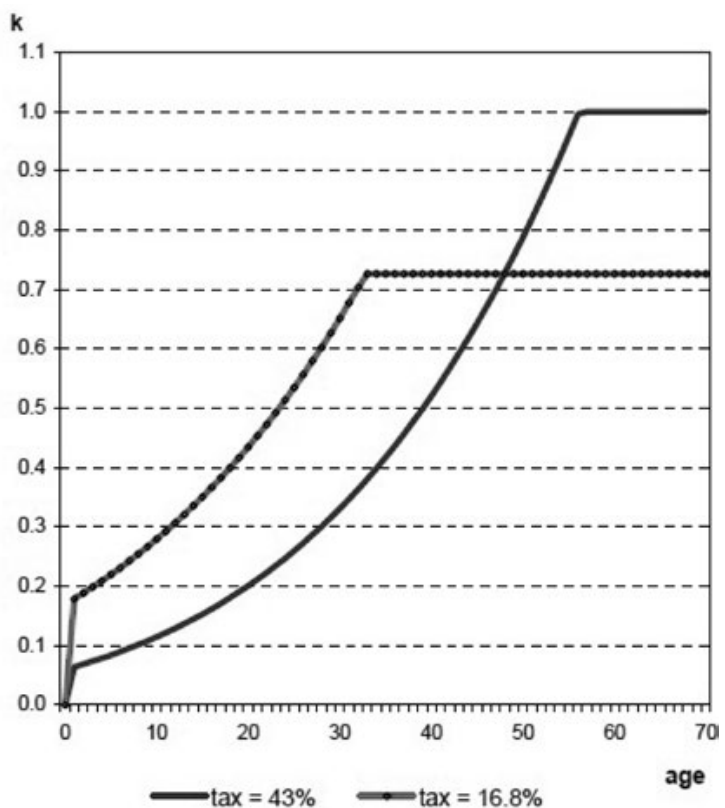

Table 3 reports the changes in firm size distribution and the output gain as a result of the tax reform. With lower dividend taxes, the share of financially unconstrained firms increases from $29 \%$ to $57 \%$, which Figure 10 illustrates more in details. As a consequence, the output share of financially unconstrained firms increases from 55\% to $68 \%$. The percentage increase in average hours per capita is $1.2 \%$, which matches the trend observed in the US at the beginning of the $1980 \mathrm{~s}$.

distribution for the U.S. business sector, there is no data on the size distribution of the U.S. corporate sector. For the first time, in 2014, the BEA published the first set of firm size distribution for the US corporate sector. However, we cannot still directly use this distribution since it includes both C-Corps and S-Corps., where the former is subject to dividend taxation, and the latter is not. Therefore, unfortunately, it is not possible for us to evaluate the success of our model in terms of its match with the actual firm size distribution of US corp. sector. 
Table 3

Taxes and Steady State Comparison

\begin{tabular}{lcc}
\hline \hline & \multicolumn{2}{c}{ Marginal Dividend Tax Rate } \\
\cline { 2 - 3 } & $43 \%$ & $16.8 \%$ \\
\hline Fraction of constrained firms & $71 \%$ & $43 \%$ \\
Output share of constrained firms & $45 \%$ & $32 \%$ \\
\hline Output level a $_{\text {Hours level a }}$ & 1 & 1.027 \\
\hline \hline
\end{tabular}

a - The levels at $43 \%$ tax rate are normalized.

Figure 10

Firm Size Distribution
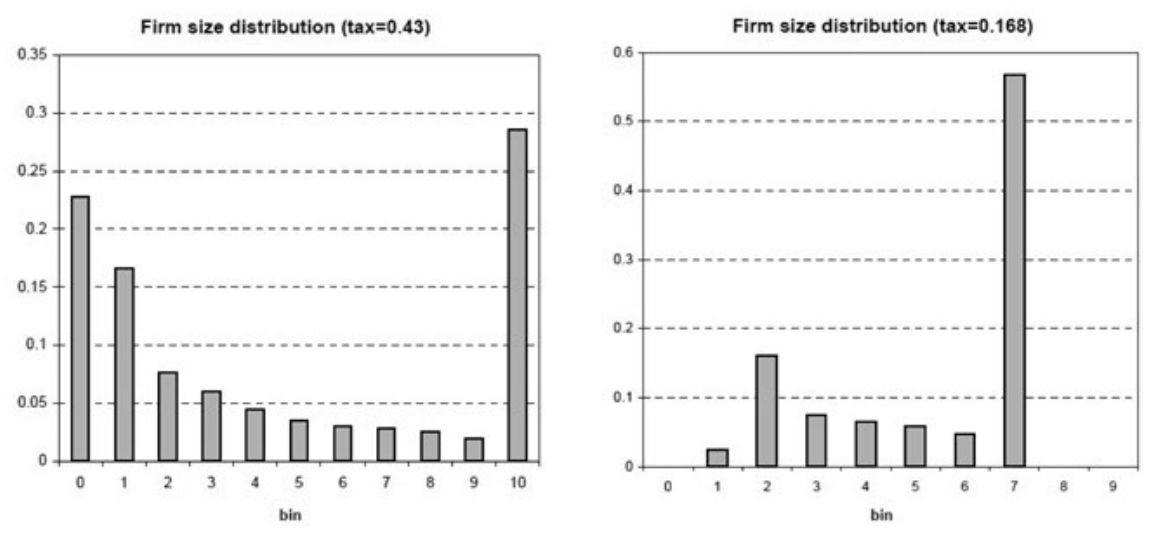

In baseline economy, the percentage increase in aggregate output across these two sample periods is $2.7 \%$. New firms that start from a higher level of capital increase the demand labor, which increases the market clearing wages. As a consequence, the optimum size for unconstrained firms decreases because of the increased cost of labor input. In equilibrium, even though the output share of financially unconstrained firms increases significantly, the tax reform does not generate large increases in output level in our economy, which is consistent with the observed growth trend in US economy.

Finally, the model is able to explain the observed differences between the stock market performance of young and old firms observed post-1984. The value of the U.S. corporate sector begin to rise starting in the mid-1980s but most of the post-1984 rise was because of increase in market capitalization of new and young firms. Contrarily, incumbent old firms experienced a stagnation in their stock market capitalization during 
the Great Moderation. ${ }^{[28]}$ In our model, with lower dividend taxes, the present discounted value of dividends increases for both young and old firms. In addition, since the capital level of constrained young firms is higher at each age interval, the market value of young firms increases after the tax reform. Contrarily, even though the present discounted value of dividends increases for old incumbent firms also, the optimum level of capital decreases because of higher wages as a consequence of increased competition in labor markets (Figure 10). Therefore, the result of tax reform on the market capitalization of old firms is ambiguous, which can be interpreted as a direct evidence for our proposed explanation.

\section{Business Cycle Implications}

In this section, we study how the business cycle volatility changes with lower dividend taxes. The business cycle implications of the income tax reform are captured by lowering the marginal dividend tax rate from a level of $43 \%$ to $16.8 \%$. Table 4 reports the standard business cycle and financial market statistics computed on model simulated data, for early and late periods.

\footnotetext{
${ }^{[28]}$ See Hobjin-Jovanovic (2001) and Jovanovic-Rousseau (2002) for a detailed analysis.
} 
Table 4

Real and Financial Market Statistics

\begin{tabular}{|c|c|c|c|c|c|c|}
\hline & \multirow{2}{*}{\multicolumn{2}{|c|}{$\begin{array}{c}1954-1984 \\
\text { Dividend Tax Rate } \\
43 \%\end{array}$}} & \multirow{2}{*}{\multicolumn{2}{|c|}{$\frac{1984-2004}{\frac{\text { Dividend Tax Rate }}{16.8 \%}}$}} & \multicolumn{2}{|c|}{ Late / Early } \\
\hline & & & & & \multirow[b]{2}{*}{ Data } & \multirow[b]{2}{*}{ Mode } \\
\hline & Data & Model & Data & Model & & \\
\hline & \multicolumn{6}{|c|}{ Financially constrained finns: 2 times more volatile } \\
\hline \multicolumn{7}{|l|}{ REAL DEVIATIONS } \\
\hline Output & 2.24 & 2.24 & 1.23 & 2.02 & 0.55 & 0.90 \\
\hline Investment & 598 & 6.88 & 4.15 & 6.26 & 0.69 & 0.91 \\
\hline Consumption & 1.22 & 0.91 & 0.53 & 0.81 & 0.43 & 0.89 \\
\hline Labor & 2.21 & 3.35 & 1.10 & 3.02 & 0.50 & 0.90 \\
\hline TFP & 0.74 & 0 & 0.42 & 0.00 & 0.57 & NA \\
\hline \multicolumn{7}{|c|}{ FINANCIAL VARIABLES } \\
\hline \multirow[t]{2}{*}{ Tobin's q } & 0.76 & 0.76 & 1.14 & 1.09 & 1.49 & 1.44 \\
\hline & \multicolumn{6}{|c|}{ Financially constrained firms: 3 times more volatile } \\
\hline \multicolumn{7}{|l|}{ REAL DEVIATIONS } \\
\hline Output & 2.24 & 2.24 & 1.23 & 1.90 & 0.55 & 0.85 \\
\hline Investment & 598 & 6.91 & 4.15 & 6.01 & 0.69 & 0.87 \\
\hline Consumption & 1.22 & 0.9 & 0.53 & 0.75 & 0.43 & 0.83 \\
\hline Labor & 2.21 & 3.35 & 1.10 & 2.85 & 0.50 & 0.85 \\
\hline TFP & 0.74 & 0 & 0.42 & 0.00 & 0.57 & NA \\
\hline & \multicolumn{6}{|c|}{ Financially constrained firms: 4 times more volatile } \\
\hline \multicolumn{7}{|l|}{ REAL DEVIATIONS } \\
\hline Output & 2.24 & 2.24 & 1.23 & 1.81 & 0.55 & 0.81 \\
\hline Investment & 5.98 & 6.92 & 4.15 & 5.74 & 0.69 & 0.83 \\
\hline Consumption & 1.22 & 0.89 & 0.53 & 0.70 & 0.43 & 0.79 \\
\hline Labor & 2.21 & 3.35 & 1.10 & 2.71 & 0.50 & 0.81 \\
\hline TFP & 0.74 & 0 & 0.42 & 0.00 & 0.57 & NA \\
\hline
\end{tabular}

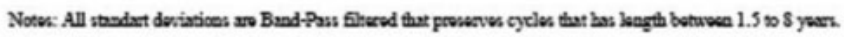

The model matches Tobin's q for pre-1984 period since the returns to scale parameter is set to replicate that statistic. The formula used to calculate the tobin's q, Tq, from our model is:

$$
T q(s)=\frac{\int V(a ; s) \mu(d A)}{\int k(a ; s) \mu(d A)}
$$

The reduction in dividend taxes increases the market value of corporations, therefore tobin's q to a level of 1.09. The mechanism works as follows: when marginal dividend tax rate is reduced, the current value of firms, which is equal to the discounted value of dividends, increases. Contrarily, the cost of reproducible capital is not affected by the dividend taxes. Therefore, the tobin's q, value over replacement cost for U.S. corporate 
sector increases as a consequence of lower dividend tax rates. Quantitatively, the model accounts for the $87 \%$ percent of the increase in tobin's q observed in the data.

For our numerical analysis, the difference in the output volatility of financially constrained and unconstrained firms is crucial. There are various studies that document the volatility differences between different sizes of firms for some particular sectors. In addition, there is a huge body of literature that studies the financial frictions and its effect on the firm size distribution and life-cycle. Unfortunately, there are no micro studies and resources that document these differential response to business cycle shocks quantitatively. Therefore, we calibrate the model for the pre-1984 period by considering three different cases (1, 2, 3 respectively), where the constrained firms' business cycle response is two times, three times and four times more volatile with respect to unconstrained firms'. In case 1 , the output volatility decreases $10 \%$ with respect to its pre-1984 level and the tax reform can account for $22 \%$ of the reduction in macro volatility. As the output volatility difference between different types of firms, the reduction in aggregate volatility generated by our model is higher. In case 2 , the output volatility decreases $15 \%$ and the tax reform can account for $34 \%$ of the reduction. Finally, in case 3 , the macroeconomic volatility decreases $19 \%$ and the tax reform can account for $41 \%$ of the reduction.

In terms of understanding the main mechanism, it is crucial to understand the differences in business cycle responses of financially constrained small and young firms, and financially uncon-strained old and large firms.

Financially unconstrained firms operate at their optimal capital level and therefore optimal labor input. A higher wage shock decreases the optimal labor input level for these firms. On the other hand, since reducing labor is costly, they choose to limit the number of workers that they layoff. Contrarily, a lower wage shock increases the optimal labor input. Since increasing labor input in a boom can be costly during downturns, they limit the number of hirings. As a consequence, old incumbent firms which are financially constrained respond less to the business cycle shocks then they should. ${ }^{[29]}$

Financially constrained firms start their life cycle at a sub-optimal capital therefore sub-optimal labor input. In response to a positive wage shock, these firms decrease the level of increase in their labor demand because of their growing labor demand on their life cycle. Therefore, the labor reduction cost does not affect the labor demand of unconstrained firms since no cost accrues. The business cycle response to a lower wage shock is also not affected since higher labor inputs during a boom does not generate a cost in recessions. As a consequence, young and small firms respond more to the business cycle shocks with respect to the old incumbent firms.

In our simulations, the differential business cycle response of financially constrained and un-constrained firms are similar quantitatively for different levels of dividend taxes. This is a general result that holds for various parameterizations according to our

\footnotetext{
${ }^{[29]}$ This can be interpreted as a natural consequence of a trade off between flexibility and operating at the efficient scale. This difference can be an explanation for the volatility differences between developed and developing countries (ongoing research).
} 
sensitivity analysis. Therefore, the more important factor that determines the change in macroeconomic volatility is the output share of each type of firm. The more financially constraint firms exist, the more volatile is the economy.

The model is successful in getting the reduction in volatility of other macroeconomic indicators: consumption, investment and labor. On the other hand, the volatility of labor input generated by the model is higher than the data. Since our specified technology does not include TFP as a variable input in production, the labor input volatility in our model captures all TFP volatility observed in the data. The model does not explain the fluctuations and the reduction in the volatility of TFP given the technology specifications. In order to explain the observed decrease in TFP volatility endogeneously, a straight forward way to extend the current model is to incorporate monopolistic competition as modelled in Jermann and Quadrini (2006) (explained in details in Appendix A). ${ }^{[30]}$

Following these results, a natural question that would arise is the following: In order to match the observed decrease in macro volatility, what will be the required decrease in the volatility of shocks (on the top of tax cuts)? We find that we need to reduce the std. dev of shock by $39 \%$ to match the observed decline in output volatility during the period of interest. This exercise shows us that, while dividend tax cuts contributed significantly to the observed decrease in macro volatility, alternative scenarios needs to be explored to explain the whole picture.

\section{Conclusion}

This paper investigates the effects of dividend tax cuts on macro volatility. It develops a general equilibrium model with heterogeneous firms and presents a novel mechanism where the business cycles are propagated by the distortions generated in equity markets by dividend taxes.

We conclude that, a policy change that implies full income tax deductibility for dividend payout would lead to a more stable economy. On the other hand, the model abstracts from the effect of dividend taxes on government budget deficit since tax revenues are rebated to households in a lump sum manner. In future work, we plan to consider the effect of dividend taxes on macroeconomic volatility in a setup where the government collects taxes to finance reforms affects the government budget deficit.

\section{References}

Ahmet, S., Levine, A., and Wilson, B.A. (2002). "Recent U.S. Macroeconomic Stability: Good Policies, Good Practices or Good Luck?," International Financial Discussion Paper No.730. Board of Governors of the Federal Reserve System.

Arias, A., Hansen, G.D., and Ohanian, L.E. (2007). "Why have Business Cycle Fluctuations Become less Volatile?," Economic Theory, 32(1): 43-58.

${ }^{[30]}$ This modelling extension is first introduced by Jermann and Quadrini (2006) to generate endogenous TFP volatilitiy in DSGE models. However, this modelling frame is quite open to debate since it implies an IRTS production at the aggregate, which seems to be inconsistent with the general consensus in the literature. Therefore, just to avoid further discussions, we avoid this extension. 
Auerbach, A. and Hassett, K. (2006). "Dividend Taxes and the Firm Valuation: New Evidence," American Economic Review, 96(2): 119-123.

Blanchard, O. and Simon, J. (2001). "The Long and Large Decline in U.S. Output Volatility?," Brookings Papers on Economic Activity, 32(1): 135-174.

Bulow, J.I., Summers, L.H., and Summers, V.P. (1990). "Distinguishing Debt from Equity in the Junk Bond Era," in J.B. Shoven and J. Waldfogel (eds.), Debt, Taxes and Corporate Restructuring: 135-166. Washington, DC: The Brookings Institution,

Campbell, J.R. and Hercowitz, Z. (2006). "The Role of Collateralized Household Debt in Macroeconomic Stabilization," Working Paper No. 16-2006.

Campbell, J.R. and Fisher, J. (2000). "Aggregate Employment Fluctuations with Microeconomic Asymmetries," American Economic Review, 90(5): 1323-1345.

------, (2004). "Idiosyncratic Risk and Aggregate Employment Dynamics," Review of Economic Dynamics, 7(2): 331-353.

Castenade, A., Diaz-Gimenez, J., and Rios-Rull, J.V. (1998). "Exploring the Income Distribution Business Cycle Dynamics," Journal of Monetary Economics, 42(1): 93-130.

Clarida, R., Gali, J., and Gertler, M. (2000). "Monetary Policy Rules and Macroeconomic Stability: Evidence and Some Theory," Quarterly Journal of Economics, 115: 147-180.

Clark, T.J. (2009). "Is the Great Moderation Over? An Empirical Analysis, Federal Reserve Bank of Kansas City," Economic Review, vol. 94(4): 5-42.

Cooley, T.F. and Quadrini,V. (2001). "Financial Markets and Firm Dynamics," American Economic Review, 91(5): 1286-1310.

Comin, D. and Philippon, T. (2005). "The Rise in Firm Level Volatility: Causes and Consequences," NBER Macroconomics Annual 20.

Davis, S.J., Haltiwanger, J, Jarmin, R., and Miranda, J. (2006). "Volatility and Dispersion in Business Growth Rates: Publicly Traded versus Privately Held Firms," NBER Working Paper.

Den Haan, W. and Sterk, V. (2011). "The Myth of Financial Innovation and the Great Moderation," Economic Journal, 121(553): 707-739.

Dietz. M.D. (2004). "Dividend and Capital Gains Taxation in a Cross Section of Firms," mimeo.

Dynan, K.E., Elemendorf, D.W., and Sichel, D.E. (2006). “Can Financial Innovation Help to Explain the Reduced Volatility of Economic Activity?," Journal of Monetary Economics, 53(1): 123-150.

Gali, J. and Gambetti, L. (2009). "On the Source of the Great Moderation," American Economic Journal: Macro, 1(1): 26-57.

Gomes, J.F. (2001). “Financing Investment,” American Economic Review, 91(5): 1263-1285.

Gourio, F. and Miao, J. (2010). "Firm Heterogeneity and the Long-run Effects of Dividend Tax Reform," American Economic Journal: Macro, 2(1): 131-168.

------, (2011). "Transitional Dynamics of Dividend and Capital Gains Tax Cuts," Review of Economic Dynamics, 14: 368-383.

Greenwood, J. and Jovanovic, B. (1999). "The Information-Technology Revolution and the Stock Market," American Economic Review, 89(2): 116-122. 
Gonzales, F.M. and Johria, A. (2002). “Asymmetric Labor Adjustment, Organizational Capital and Aggregate Job Flows," mimeo

Gordon R.J. (2005). "What Caused the Decline in U.S. Business Cycle Volatility?,” NBER Working Paper 11777.

Hall, R.E. (2001). T"he Stock Market and Capital Accumulation," American Economic Review, 91(5): 1185-1202.

Hobin, B. and Jovanovic, B. (2000). The Information Technology Revolution and the Stock Market: Evidence," American Economic Review, 89(2): 1203-1220.

Hopenhayn, H. and Richardson, R. (1993). "Job Turnover and Policy Evaluation: A General Equilibrium Analysis," Journal of Political Economy, 101(5): 915-938.

Jermann, U. and Quadrini, V. (2006). "Financial Innovations and Macroeconomic Volatility," NBER Working Paper 12308.

Kahn J.A. McConnell; M., and Perez-Quiroz, G. (2002). "On the Causes of the Increased Stability of the U.S. Economy," Federal Reserve Bank of New York, Economic Policy Review, 8: 183-202.

Krusell, P. and Smith, A.A. (1998). "Income and Wealth Heterogeneity in the Macroeconomy," Journal of Political Economy, 106(5): 867-896.

------, (1997). "Income and Wealth Heterogeneity, Portfolio Choice, and Equilibrium Asset Returns," Macroeconomic Dynamics, 1(2): 387-422.

Kydland, F.E. and Prescott, E.C. (1982). "Time to Build and Aggregate Fluctuations," Econometrica, 50(6): 1345-1370.

Laitner, J. and Stolyarov, D.L. (2003). "Technological Change and the Stock Market," American Economic Review, 93(4): 1240-1267.

Leduc, S. and Sill, K. (2005). "Monetary Policy, Oil Shocks and TFP: Accounting for the Decline in US Volatility,” Working Paper, FRB Philadelphia.

McConnell, M. and Perez-Quiroz, G. (2000). "Output Fluctuations in the United States: What has Changed since the Early 1980s?," American Economic Review, 90(5): 1464-1476.

McGrattan, E.R. and Prescott, E.C. (2005), "Taxes, Regulations, and the Value of U.S. and U.K. Corporations," Review of Economic Studies, 72: 767-796.

Philippon, T. (2003). "An Explanation for the Joint Evolution of Firm and Aggregate Volatility," Working Paper.

------, (2016). "Brexit and the End of the Great Policy Moderation," Brookings Papers on Economic Activity, Fall 2016.

Poterba, J.M. and Summers, L.H. (1983). "Dividend Taxes, Corporate Investment, and Q," Journal of Public Economics, 22: 135-167.

Shoven, J.B. and Waldfogel, J. (1990). "Introduction and Summary," in J.B. Shoven and J. Waldfogel (eds.)., Debt, Taxes and Corporate Restructuring: 1-20. Washington, DC: The Brookings Institution.

Stock, J.H. and Watson, M.W. (2002). "Has the Business Cycle Changed and Why?," NBER Macroeconomics Annual.

Taylor, J.B..(2013). “The Effectiveness of Central Bank Independence Versus Policy Rules,” mimeo. 


\section{Appendix A - Endogenous TFP Volatility: Model}

The modeling of endogenous TFP Volatility is based on the same setup described in the text, except the production and market structure. Each firm produces a differentiated intermediate good $\mathrm{y}$, which is used in the production of a competitive final good Y, with technology:

$$
Y(s)=\int\left(y(a ; s)^{\eta} \mu(d A)\right)^{\frac{1}{\eta}}
$$

The final good producers use intermediate goods as inputs in production and determine the price of each input by their demand. The price of each intermediate good is:

$$
p(a ; s)=Y(s)^{1-\eta} y(a ; s)^{\eta-1}
$$

where the price of final good is normalized to 1 . We used symmetry property in the model: all operating plants with the same individual state set the same price. The intermediate good is produced with capital and labor according to:

$$
y(a ; s)=z\left(k^{\alpha} l(a ; s)^{1-\alpha}\right)^{v}
$$

where the returns to scale parameter is greater than unity, $v>1$. This assumption will capture the idea of increasing returns to scale at the firm level, which basically interpreted as capturing the variable capital utilization and labor hoarding. The monopoly revenue that the intermediate good producers take into account is:

$$
p(a ; s) y(a ; s)=Y(s)^{1-\eta} z^{\eta}\left(k^{\alpha} l(a ; s)^{1-\alpha}\right)^{v \eta}
$$

It is a well known fact that equilibrium doesn't exist in competitive economies with increasing returns to scale. Since our market structure is a monopolistic competition environment, equilib-rium exists. Even though production structure has increasing returns to scale property, the revenue function that firms consider exhibits decreasing returns to scale as long as $v \eta<1$.

The computation of TFP from the data assumes that the production function is CobbDouglas, $Y(s)=Z K(s)^{\alpha} L(s)^{1-\alpha}$, where $\mathrm{K}, \mathrm{L}$ and $\mathrm{Z}$ are aggregate capital, aggregate labor and TFP level respectively. This production structure assumes that the output increases linearly with the inputs. On the other hand, increasing returns to scale assumption in our model implies that the output increases more than linearly. Therefore, TFP from the model is calculated as follows:

$$
T F P=Z(s)=\frac{Y(s)}{K(s)^{\alpha} L(s)^{1-\alpha}}
$$

where $Z(s)$ indicates the TFP generated by the model. Firms need to know their individual price to solve their maximization problem. The inverse demand function for an intermediate good producer depends on its individual output and the aggregate output. Firms need to know the aggregate output to solve their optimization problem. On the other hand, aggregate output is affected by the individual output of intermedi- 
ate good producers. Following the Krusell-Smith (1997-1998) methodology, we define an aggregate output belief function and assume that it is a common belief among all intermediate good producers. Given the aggregate output belief as a function of current state $\Psi(s)$, the problem of intermediate good producers is well defined.

\section{Appendix B - Data Description}

As mentioned before, we end our data analysis (macro data and dividend taxes) ends at 2004. The reason for that is the following. Our proposed conjecture focuses on dividend tax cuts that took place in the early 1980 s (from $43 \%$ to $16.8 \%$ ). On the other hand, the Bush Tax Reforms signed in 2003 (effective in 2004) - (Jobs and Growth Reconciliation Tax Act of 2003) - initiated temporary cuts (for 5 years) in dividend taxes (a reduction of 5 percentage points). Since our model focuses on the effects of permanent tax cuts and is not suitable to analyze transitional dynamics, we do not include the post-2004 period in our analysis. In any case, we should mention that our data analysis is not sensitive to this omission and, secondly, the end date of the Great Moderation period (denoted as 2007) is a rough date.

The macro, financial and equity data for corporate sector are from NIPA Accounts, Flow of Funds, Bureau of Labor Statistics and Hall (2001). The only missing variable, labor input, is calculated as the hours worked at private business sector multiplied by the ratio of corporate sector's output share at private sector output. All macroeconomic indicators are Band-Pass filtered that preserves cycles from 1.5 to 8 years. Alternative filters, such as HP filter obtain very similar results. The reason that we used Band-Pass is that it is gives more accurate outcomes for short time-series data sets that has recessions close to the beginning or end of the samples. The dividend tax rate on distributions are from McGrattan-Prescott $(2003,2005)$.

Figure 2 plots five year moving average of corporate sector output growth volatility. The standard deviation reported at time-t is the standard deviation over quarters $t-10$ to $t+10$, where a period of 21 quarters are used for calculations. The mid-period is chosen as the indicators since the end of period or beginning of period choices gives too much importance to far ends and shifts the timing of changes approximately 4 quarters before or after.

\section{Appendix C - Computation of Steady State}

Step 1: Choose a discrete grid in the space of capital and labor such as $k \in \Delta k=\left\{k_{1}, k_{2}, \ldots k_{n}\right\}$ and $l \in \Delta l=\left\{l_{1}, l_{2}, \ldots l_{n}\right\}$, where $k_{1}=0$ and $l_{1}=0$.

Step 2: Guess the wage rate w which is constant in the steady state. Since we are analyzing the deterministic version of our model, the equilibrium interest rate $r$, is equal to the $(1 / \beta)-1$. 
Step 3: Guess the initial values for functions, $V_{k}\left(k_{i}, l_{j}^{-1}\right)$ and $V_{l}\left(k_{i}, l_{j}^{-1}\right)$ for $i \in\{1, \ldots, n\}$ and $j \in\{1, \ldots, m\}$ The values outside the grid points are joined with bilinear approximation.

Step 4: Solve for the policy functions of the firm $d(),. k^{\prime}($.$) and l($.$) .$

Step 5: Use the guessed policy functions to guess new values for $V_{k}($.$) and V_{l}($.$) ,$ and restart the procedure from Step 4 until convergence.

Step 6: After convergence, find the optimal size of outside equity issuance and determine the initial size of new firms, $k_{e}$ using the condition:

$$
V_{k}\left(k_{e}, 0\right)=\frac{1+r}{1-\phi}
$$

Step 7: Using the initial level of capital and policy rules, compute the size distribution of firms. Given the distribution of firms, compute the demand for labor $L_{d}$, output $Y$, consumption $C$ and investment $I$ in the economy. Check if the labor market is in equilibrium. If not, update the wages and restart the procedure from Step 1 until the labor markets clear.

\section{Appendix D - Computation - Business Cycle}

At each point in time the states of the economy are (i) the wage rate w and (ii) the distribution of firms over capital and employment history represented by the measure $\mu$. The aggregate state of the economy is $s=(w, \mu)$.

One difficulty with the computation of dynamic stochastic heterogeneous agent models is deriving and keeping track of the distribution. Therefore, the dimension of the state vector must be decreased for computational tractability. We adopt the methodology of Krusell-Smith $(1997,1998)$ to approximate the state vector $s=(w, \mu)$ with a smaller vector $s=(w, E)$, where $\mathrm{E}$ is a vector of elements derived from $\mu$. The algorithm follows Krusell-Smith (1997) closely as follows:

Step 1: Choose a discrete grid in the space of capital, employment history, and moments rep-resenting the true distribution of firms $\left(k, l_{-1}, E\right)$.

Step 2: Guess a functional forms for $\Gamma(\mathrm{s})$ and $\Omega(\mathrm{s})$. Guess values for the parameter vectors $\varsigma_{\Gamma}$ and $\varsigma_{\Omega}$ for both functions. The firms problem is well defined given the functions for law of motion and pricing. 
Step 3: Using the functions for law of motion of distribution of firms and for the prices, solve for $v\left(k, l_{-1} ; s\right)$, as it is described in detail in APPENDIX C. ${ }^{[31]}$

Step 4: Simulate the economy for a large number of periods, T . Solve the model each period with a large number of cohorts. ${ }^{[32]}$ Record the actual distribution of firms $\mu$ and prices $\varpi$ at each point in time, $\mathrm{t}=1, \ldots, \mathrm{T}$. Use the recorded distribution of firms to build the time series of the moments $\mathrm{E}$.

Step 5: Use the obtained time series to derive the new functions for law of motion of distribution and prices, $\Gamma^{*}(\mathrm{~s})$ and $\Omega^{*}(\mathrm{~s})$. If the distance between the coefficients of the new and old functions are less than a predetermined tolerance level, stop. Otherwise, go back to step 3 and continue the procedure by using the new coefficient for the functions.

Step 6: Upon the convergence of parameter vectors $\varsigma_{\Gamma}$ and $\varsigma_{\Omega}$, the goodness of fit statistics may be analyzed. If the fit is not satisfactory, try richer functional form for $\Gamma$ (s) and $\Omega(\mathrm{s})$, and/or increase the set of statistics that represent the firms distribution, and go back to Step 1 .

\footnotetext{
${ }^{[31]}$ Different than the computation of steady state, we use penalty function method to handle the non-negativity constraint on dividends. Therefore, we assume that the equity is issued only by the entrants, as it is observed in steady state analysis. This methodology simplifies the computation significantly. Also, this assumption is verified as a fact in our supplementary partial equilibrium analysis, therefore expected to hold in general equilibrium.

${ }^{[32]}$ For details of the solution algorithm, see Krusell-Smith (1997).
} 